\title{
Policy Strategy of Government Services To Women Victims of Domestic Violence
}

\author{
Hamdanah \\ Faculty of Social and Political Sciences, University of Jember
}

\begin{abstract}
Public view of domestic violence has been undergoing a paradigm shift from previously considered private problem to a public issue. Thus, government interventions in this area are badly needed. This study aimed to (1) describe the expectations of women victims of domestic violence to public organizations; (2) Supports and barriers of prevention and management of domestic violence, and (3) determine the strategy and implementation of prevention and services to women victims of domestic violence associated with gender fairness. This is a qualitative study using phenomenological approach. The research location was in Jember Regency, East Java Province, Indonesia. The results showed that women victims of domestic violence expected all parties respect the decisions on wanting to divorce with their husbands who had been violent. The forms of respect were the facilitation and acceleration of the process of divorce either in scope of the institution where the husband/women worked, the prosecutor and the court. Meanwhile, Jember Regency government supports through local legislation, Regent's Decree/Regulation on the establishment of the Integrated Service Center for Regency Level, Complaint Post at District level and Griya Asih (Home for Service) at Village/administrative village level. Similarly, the supports are given through 12 organizations/government agencies/bodies and 3 $N G O s$ on women's empowerment, including the protection of women and children. However, these activities still experience some constraints in structure level, patriarchal culture, personality, interpretation of religious teachings and systems of regulation. Furthermore, the strategy and implementation of services to women victims of domestic violence associated with gender kesataraan is by top down and bottom up approach.
\end{abstract}

Keywords: Government, Women, Violence

\section{Introduction}

Domestic violence was originally considered only a minor problem and was never seriously discussed because it was considered a privacy problem. Most people still think that domestic violence is a personal problem. However, violence against women is considered serious and becomes a public issue since, in addition to impacts on the victims, it has effects on children. Besides, the problem of domestic violence experienced by wives also impacts negatively on the wider at larger scale.

In order to handle this problem, the Indonesian Government has enacted the Law on the Elimination of Domestic Violence (UUPKDRT) No. 23 of 2004. The publication of this Act indicates that the issue of domestic violence is no longer considered to be something private but has become a public issue. Therefore, the prevention, protection, and treatment to the victims and law enforcement to the perpetrators should be carried out in professional, proportional, and integrated way by the police, court, prosecutor, hospital, social workers, companion, spiritual mentor and advocate. The Law on domestic violence elimination is a public policy that has done a groundbreaking law since there are some criminal law reforms that have not been regulated by previous Laws followed by the Law on Witness and Victim Protection No. 13 of 2006 and Law on Trafficking Elimination No. 14 of 2009.

Domestic Violance, especially that experienced by wives, is a bitter and distressing reality experiences by wives, violence women victims (Elly, 1997; Jannah et al, 2003; Kleden et al, 2009; and Noerjannah et al, 2009). Domestic violence, particularly that committed by husbands against wives, occurs not only in developing countries. Studies in the UK and North America conclude that domestic occur in one of four families and that one in ten women experiences violence from their spouses (New South Wales Child Protection Council, 1965). Hayati (1997) tries to describe and break the silence on violence against women, particularly domestic violence. Violence against women (VAW) and domestic violence are nationally reported to increase. Based on data from the National Commission for Women, it can be seen that in 2004 there were 13,968 VAWs and 4,310 domestic violence and increased to 119,107 VAWs and 113878 domestic in 2011. Based on the initial search, factually not all cases served by the Integrated Service Center were resolved through legal channels; it is estimated that $40 \%$ were resolved through mediation and could not be continued due to lack of supporting evidences, even the revocation of the case files.

The implementation of services to victims of domestic violence is not an easy matter. This involves many factors, such as human, technology support, socio-cultural factors, also factors of religious values and 
public service performance. The study on the strategy of government services to women victims of domestic violence is very interesting and important, for several reasons. First, the government is regarded as the new hope for the community members to public officials to which the implementation leads to values that uphold the protection of the citizens' rights. Thoha (2011) uses the term Human Governance for the new culture of public administration; it can also be called an attempt to humanize Public Administration. Human Government arises due to the emergence of issues and perspectives of method and structure to meet the basic expected principles in the arrangement of good governance. The four important bases for good governance that drive the need for Human Governance are, among others: (1) desire to create a better service order. Those events and activities that occur after the issuing of authoritative and the substantive impact and people events (Mazmanian \& Sabatier (1986:4), Jones (1977), Dunn (1981), Abdul Wahab (1991)); (2) more investment in the field of information and technology, (3) putting better regulation, (4) training on human resources management which is more transparent and honest (Thoha, 2008).

Second, operationally, the public interest is often a problem as formulated through a process that often does not reflect public aspirations (Keban, 2008), in this research aspirations of women as victims of domestic violence. Cases of domestic violence should be given a serious attention because violence is contrary to human rights; it is, therefore, necessary to establish services from a competent and professional bureaucracy, which has the sense of responsibility and professionalism in performing the mandated major tasks, functions, and responsibilities (Masdar in Widodo, 2006).

Masdar (in Widodo, 2006) writes that the professional bureaucracy is a bureaucracy that has high competence, including knowledge, expertise, skills, attitudes, and behaviors required to preserve the mandated tupoksiwab (major tasks, functions, and responsibilities). The professional and competent bureaucracy will surely be able to achieve optimum performance order. Professionalism becomes a topic considered in various fields, including public administration; in general, the profession of classified positions includes knowledge related to the profession. Professional status is based on the ability of professionals to translate knowledge into action and to use their knowledge to help others whose problems are not resolved (Gargan, 2006:1126-1127). Cases of domestic violence are the implications of wrong understanding of gender; therefore, it is important to view and analyze whether the policies formulated, implemented and evaluated are truly gender responsive.

Based on this review, this study aimed to (1) describe the expectations of women victims of domestic violence to public organizations; (2) Supports and prevention barriers of domestic violence management, and (3) determine the strategy and implementation of services to women victims of domestic violence associated with gender fairness.

\section{Research Methods}

Analysis Approach. The approach taken in this study was phenomenological approach (Philipsan 1972; 121. Ijsseling 1979; 5). It is expected that this approach could help researchers in (1) observation, (2) imagination, (3) abstract thinking, and (4) feeling or appreciating the phenomena in the field (Yuswadi, 2005). Thus, the empirical findings can be described in more details, more clearly, and more accurately.

Determination of Research Location. This research was conducted in Jember Regency, East Java Province, Indonesia. The determination was based on: first, the reality that in Jember there are a lot of cases of domestic violence committed by husbands against wives (54 cases in 2010, 40 cases in 2011, 51 cases in 2012 and 42 cases in 2013) as reported to PPT (Integrated Service Center) (data from PPT 2013); second, socioculturally, in Jember there are two major Ethnics, namely Java and Madura, which automatically are very different in addressing domestic violence; third, geographically Jember is known as Education Town and town of santri (students studying at an Islamic boarding school called pesantren) which will also be interesting if it is associated with behavior and thought pattern of society.

Unit of Analysis. In this study, the unit of analysis was the institution that managed and served victims of domestic violence in Jember regency. The unit of analysis was limited to Women Empowerment Agency, Education Department, POLRES (Police District Department), PPT (Integrated Service Centre) and Griya Asih.

Data Collection Methods. This study gathered data from three parties; first, public officials who provided services to domestic violence cases (cases that had been or were being managed by PPT), caretakers of two non-government organizations (NGOs); second, the women experiencing the cases of domestic violence which were not reported to PPT in order to obtain data on the barriers in efforts of management and services to women victims of domestic violence and to find out public trust; third, women victims of domestic violence who had the courage to report the abuse to the authorities. The data were get answers on the experiences suffered by women victims of violence in undergoing assistance services and advocacy. To obtain the needed data, the methods used in this study were life history, in-depth interview, observation, focus group discussion (FGD) and documentation.

Determination of Informants and Data Sources. In qualitative research, there are three stages in the selection of informants: (1) Selection of key informants chosen purposively (Bungin (2007; 53), Michaell, 
Quinn Patton (1980)); (2) Termination of informant selection when it is considered not to find another variation of information. The key informants in this study were the Regent of Jember, Head of Women Empowerment and Family Planning Agency, Head of Education Department, Head of Integrated Service Center, Chief of Police Department, two NGO Boards, two businessmen, two members of Parliament and Chairman of Griya Asih Tegalsari village, District of Ambulu. Then, the female victims of domestic violence were 10 people; 8 people who reported the cases to PPT and 2 people who did not report the cases to PPT, two informants with status as teachers (Civil Servants), 1 person as a public official wife who did not report the case to PPT.

Data Analysis. Data analysis was performed at any time of field data collection on an ongoing basis. Data obtained from observation, in-depth interview and focus group discussion were analyzed and organized into specified categories with reference to the points of discussion that had been established in the study. In this analysis, interpretation was done for the provision of meaning on the existing social and cultural facts through the linkages between the various phenomena through this effort. It is expected that wide range of socio-cultural phenomena that had to do with the perspective of governance and service quality to women victims of domestic violence could be clearly and well described, so the research could be close to the reality. Peer debriefing was done with the colleagues to obtain a wide range of inputs and criticisms to make the quality of the analysis more accountable. This was done by inviting them to gather together in a discussion or visiting them one by one while comparing their criticisms. Similarly, audit trail was conducted to test the accuracy of data (field notes, recording documents and photos), data analysis (summary, concepts) results of data synthesis (interpretations, conclusions, definitions, patterns of literature relationship, and final reports) and the processes used (methodologies, design of strategies and procedures) whereas member check was carried out with the informants, i.e. asking again about the statements that had been summarized in the understanding of researcher, to ensure the correctness of meaning that had been made. In this way, cross check and confirmation can be undertaken at the same time in drawing conclusions from the information that has been recorded by the researcher (Yuswadi, 2005). Furthermore, triangulation was also used as a combination of methods in studying phenomena or similar programs. The activities in data analysis were data reduction, data display, and conclusion drawing/verification. The interactive model of analysis is as follows: Figure 1. Components of Data Analysis: Interactive Model (Miles and Huberman, 1994)

\section{Results And Discussion}

Expectations of Women Victims of Domestic Violence to Public Organizations. As victims of domestic violence, there were many expectations for public organizations in order to provide the best services to the victims of domestic violence to the government, police, prosecutors, judges and community leaders and business people. In addition to the best services, there were a few basic needs which, according to the victims, became expectations in order to gain attention from public organizations. The theory of Maslow (in Abraham 2007) on Human need (1987) states that the needs for food, drink and place to live are core needs which become the expectations of victims of domestic violence. Besides, the victims also needed independence and freedom as well as the assurance of safety and security and freedom from fear and threats often obtained from perpetrators of domestic violence. Similarly, victims also needed love and affection from the society as well as appreciation and respect to be more confident. These needs were expectations of female victims of domestic violence to public organizations and the society.

There were some expectations of victims of domestic violence to the existing public organizations. One of the expectations was expressed to the Regent as the government representation. One of the informants said:

"To Mr. Regent, I hope that a female teacher who experiences domestic violence gets facilitation in order that her permit for divorce not to be complicated even for the reason for mediation and for the sake of harmony. I guess if a female teacher has decided to propose for divorce, the case certainly could not be resolved by peaceful means and rujuk (reconciliation). Moreover, if the data and evidence of violence experienced have been complete, Mr. Regent should go down to the bottom, so you will know how difficult and complicated the divorce process proposed by the wife is. I also hope safety assurance of my soul because many times my husband threatened to kill me. (Interview on October 18, 2013).

Various kinds of expectations were conveyed by the victims to the Regent as a policy maker dealing with the necessities of life, food, shelter, security and respect from others and with the handling procedures and services for domestic violence perceived which is very procedural and complicated.

Meanwhile, to the Religious Court the victims also hoped that in mediation it did not recommend to always keep the integrity of the victim's household; if a wife sues her husband to divorce, there must be reasons that have already been maturely considered. According to the victims, so far the Religious Court's view of the problems faced by women who proposed divorce was still very biased as if the women could not be sholehah (religiously good) wives and did not want to keep the integrity of the household. In other words, the Religious Court less considered and understood the problems occurred and experienced by women. The Religious Court still had not been able and willing to hear the voices of women as victims, especially if the offenders were able 
to pay for a lawyer who could change perceptions and problems, so the victims did not get their rights; instead, they were blamed and disadvantaged. Further, the expectation of the victims to the Religious Court was that it could serve with a sense of love and respect for the rights of the victims, so that the victims could feel if their rights as victims would be respected and honored.

"I am a lay woman, but because I always got physical abuses and never got a living, I, accompanied by a companion of PPT, proposed for divorce. However, I feel that the treatment from officers in the Religious Court complicated me, with incomplete matters, and finally the session was postponed 2 months again. I've attended sessions for more than 6 times, until now there has been no decision. I as an ordinary person hope the Judge to facilitate and help a woman like me, not to even make it complicated" (interview on 12 April 2013)

This issue, when seen in the perspective of gender analysis, shows that women victims of domestic violence do not get appropriate access in line with the victims' expectations, even there is no opportunity to convey what the husbands did on the victims. Consequently, the victims felt that their rights were neglected by hidden interests. Women victims of domestic violence also have no rights to control the problems faced. What is to be disclosed is not at all in line with their expectations because the control of what can and what cannot be delivered before the judge becomes the judge's prerogative. This will make the treatment and decision taken by the judge potentially violate the principles of gender fairness. The Religious Court assistance that should be a hope for justice becomes questionable and criticized. Faqihuddin (2013) points out that the Religious Court judge must be free from the shackles of religious terminology, so that his strategic role for the sake of domestic violence eradication can run maximally; the judge must first recognize the relation of inequality between women and men, gender discrimination and injustice. From the recognition, the judge can then holistically comprehend the case of domestic violence victims by the side of the women as the victims.

Meanwhile, to the head Education Department, the informant stated that if the victim is a teacher, the Education Department should help accelerate the process, instead of making it more complicated and even utilizing this to get rewards. The Education Department did not need to, by the reason for guiding its personnel, always advises them not to propose a divorce. The reason is that the teacher should set an example in the community, regardless of that if the women teachers always obtain violence from their husbands. In this case, they have the full rights to demand for divorce.

The expectation of the victims to the prosecutors I that if domestic violence has been reported to the police and the files have been transferred to prosecutor, the victims hoped that the investigation process run shortly. Furthermore, the victim hoped that the perpetrators were prosecuted with a punishment as fairly as possible.

The victim's expectation was also addressed to public figures who often gave religious lectures;

"To all Kiyai and Bu Nyai (religious leaders who usually lead an Islamic boarding school), I hope when giving out lectures, the principles of truth and justice are always concerned in the speech, not even always stating postulates from Koran and Hadith with the interpretation that causes justification on the behavior of husbands who commit domestic violence." (Interview on February 2, 2013)

The religious and community leaders are expected to help clarify the public understandings which often give negative stereotypes to women who dare to propose a divorce. The victims also hoped that they received awards and honors, so that they were confident to get up and be able to realize self-actualization and develop their own potentials as members of community without suffering humiliation and insults from the public because of their status as widows.

Support and Barriers to Prevention and management of Domestic Violence. Policy support and services of prevention, completion and management of domestic violence in Jember Regency are specifically implemented by Women Empowerment and Family Planning Agency (BPPKB) Jember Regency based on Jember Regent's Decree No. 39 of 2008 which instructs the Women Empowerment and Family Planning Agency Jember Regency as the implementer of Local Regulation No. 4 of 2008 on the Protection of Women and Children Victims of Violence. To improve the efficiency and effectiveness of the intent and purpose of the prevention and management of domestic violence, the implementation is in cooperation with NGOs, Police, Agencies/Institutions and organizations that have concerns with programs on women empowerment activities, including the protection of women and children. There are 12 government organizations/agencies and 3 nongovernmental organizations undertaking these.

Organizations/government agencies include Women Empowerment and Family Planning (BPPKB) which, in carrying out its duties and functions, implements the programs: (1) the development of Integrated Service Center (PPT) for victims and/or witnesses of domestic violence, Trafficking and Children Protection, (2) Building capacity and institutional network of women and children empowerment; (3) Institutional Strengthening on Mainstreaming Gender and Children; (4) Increasing participation and gender fairness in development (P2WKSS); (5) Program for Women Empowerment in Local Economic Development (P3EL) (6) Increasing women participation in rural areas. Education Department has a program of preventing, reducing and eliminating domestic violence by increasing Human Resources (HR). This is carried out by forming KF 
(functional literacy) Group for productive-aged people in order to increase their knowledge and insights, so that they are not easily fooled. Another activity in economic violence prevention effort is by providing training (Life Skill) for women, that is, Training on Sewing Skill, TKK, TKR, TRP and Embroidery. Community Development Agency carries out activities in support of Domestic Violence Prevention by providing Women Savings and Loans (SPP) to reduce economic, physical and psychological violence. Total of SPPs was 3,580 (three thousand five hundred and eighty) groups covering 38,510 women beneficiaries.

Manpower and Transmigration Department organizes activities that prioritize Women Empowerment through Education, Training, and Skill Training for job seekers on manufacturing soy milk, entrepreneurship training by making beaded bags. It also conducts training and empowerment for transmigration participants on manufacturing tofu, fish-based food processing. Bakesbang (Agency for National Unity) provides extension on increasing tolerance and harmony in religious life, prevention of exploitation of underage children, solidarity and social cohesion among the community members, RANHAM, Counseling on Liquor and Drugs Circulation Prevention, and others. Social Department holds socialization and child advocacy and empowerment of Trafficking victims of domestic violence. The activities undertaken are Skills Training and Learning Work Practices for Waif Children including street children, disabled children and brats, Socialization of Law on Child Adoption, Law on Domestic Violence Prevention and Trafficking, fostering institutional orphanages and social institution empowerment. Public Welfare Section provides assistance in the form of grant money to improve the women's lives. The grants are for institutions such HWK, Perwosi, Muslimat NU, Moslem and Islamic preaching groups and IPPNU (Nahdlatul Ulama Student Association). Law Section conducts preventive activities through Legal Counseling and Guidance on Kadarkum (Family Law Awareness) by socializing Law No. 23 of 2004 on Domestic Violence Prevention. Ministry of Religious Affairs of Jember Regency handles domestic violence cases through Advisory Board on Counseling and Marriage Preservation (BP4) Jember Regency. Religious courts handles domestic violence cases by forwarding the cases that cannot be solved to legal institution and ultimately will lead to divorce if they cannot be mediated. Cooperatives and SMEs Department socializes cooperatives to make people avoid moneylenders and ijon system (selling farming yields while the crops are in young age). Efforts made to prevent domestic violence are by providing support, developing women cooperatives in order to increase family income and provide training for women to be independent. Dharma Wanita Persatuan (Women's Organization in government institution) Jember Regency participates to succeed government programs in the prevention of the crime of domestic violence through the activities that have been implemented such as: a) increasing productive economy of the members; b) human resource development which is expected to increase the members' independence.

Meanwhile, non-governmental organizations such as Muslimat NU (Nahdlatul Ulama Women Organization) Jember have conducted entrepreneurship training, which is in line with the mission of Muslimat NU Jember Board, one of which is to empower community members by improving economy, education and health, especially for the dhu'afa (poor people), Mother and Children. The increasing of economy of members accompanied by the improved Human Resources is also expected to increase the independence of members that have an impact on reducing one of the causing factors of the occurrence of domestic violence. Fatayat NU Jember carries out publications and socialization on domestic violence issues through regular meetings. It has also established LKP3A (Consultation Institute for Women Empowerment and Child Protection) to provide counseling and assistance to women and children in collaboration with Griya Asih and PKK (Empowerment Family Welfare) in village or regency. DPC Aisyah (Muhammadiyah Women Organization) advocates various social issues, especially women victims of violence, trafficking and child by the formation of WCC (women and children crisis center) with the name WCC As-Sakinah.

In this effort, the government of Jember also provides incentives as one of the important supporting factors. Incentive is remuneration received by bureaucratic apparatus of government in carrying out government duties to improve the performance and motivation in serving the public. Services to women victims of domestic violence are tasks to be executed by BPPKB, District Police and several related agencies, or structurally the section which is in line with Perbub (Regent's Regulation) is the Integrated Service Center (PPT). The improvement of the quality of service to victims of domestic violence must be followed by an increase in bureaucratic incentives.

The results showed that civil servants at Women Empowerment and Family Planning Agency (BPPKB) have been given incentives in accordance with the applicable income provisions because matters relating to revenue or incentives are set in laws and regulations that need to be accounted in accordance with the rights. Similarly, the majority of PPT boards who are government employees also receive incentives in accordance with the existing regulations. For civil servants, salaries or incentives are granted by Law No. 43 of 1999. Civil servants/Indonesian armed force members or police have the rights to receive salaries and allowances, and the rules continue to change or improve. For non-permanent employees, the incentives received are still low depending on the years of service. This is still below the minimum wage of Jember Regency; in accordance with the Decree of East Java Governor No. 188/433/KPTS/013/2008, the minimum wage is IDR 
770,000/month supported by Regent's Recommendation No. 580/1894/4.36.322/2008 dated 15 September 2008.

Meanwhile, there were several obstacles in providing services to women victims of domestic violence in the form of structural barriers, patriarchy culture barriers, barriers of religious doctrine interpretation that is incompatible with the noble values and basic principles of religion, and personality barriers.

Structural Barriers. One of the primary functions of government is to provide public services, so that the most basic duty of government is to provide the best service to the public. Decree of Minister of State Apparatus Empowerment No. 81 of 1993 which is later refined by the decision of the Minister of State Apparatus Empowerment No. 63 of 2004 states that the public service is all service activities undertaken by public service providers as an effort to meet the needs of service recipients as well as the implementation of the provisions of laws and regulations. All types of services performed by central and local government agencies and state-owned enterprises or regional-owned enterprises in the form of goods or services are in efforts to meet the needs of society as well as in the implementation of legal provisions.

Services to women victims of domestic violence are one part of the form of government services to the public; therefore, the victims' interests should get consideration from public officials. The issue of domestic violence cannot be seen only as an individual problem because the problem of domestic violence is also structural. In this case, in fact, most of public organizations in society have not yet made gender fairness as the main stream. Government and public organizations are in general still gender biased. Many local government agencies and private organizations have not explicitly or implicitly had gender fairness mission and have not existed to struggle for justice and gender equality. In the analysis of radical feminism activists, violence against women occurs either in public sector or in domestic sector is systemic and not always physical. Gender violence has been institutionalized through the legal system. Radical feminism is the movement of human liberation from all forms of gender injustice that occurs within the family, school, society and the State. Radical feminism attempts to destroy patriarchal authority structures that exist in every human life which become barriers to realize the liberation.

Patriarchy Culture. In the literature of cultural anthropology, Ihromi (2000) says that at first, the concept of patriarchy was used to refer to the social structure in which the father or eldest male (patriarch) had an absolute power in the family, so he controlled other family members. Patriarchal culture is a system of values and paradigms to life by placing men and women in different positions and roles. Men are positioned higher, superior and dominant, while women are positioned subordinate, inferior and low. This will have implications on the attitudes and behaviors that lead to the emergence of gender inequality and violence against women (wives). The status of "head of family" that is generally attached to the husband has the connotation of "absolute power" given to the husband, while the label as "housewife" or "queen of the household" precisely positions women as a domestic creature whose job is always dealing with affairs in kitchen, wells, bed, and they are considered as the main tasks of a wife; "devotee" and "servant" of husband. Patriarchy has been constructed, internalized and socialized since in the family, school and society even religious interpretations to State policy. Therefore, patriarchy has been well entrenched and rooted and has been dominating throughout male and female. Culturally, Jember people are famous with the majority of Madurese ethnic which is very thick of patriarchal culture. The research results showed the strong patriarchal culture both within the bureaucracy and within the society.

Patriarchal culture remains deeply embedded in the ways of thinking and behaving of the policy makers. One of small examples is the statement that has been addressed by a judge who declares that a wife who dares to propose a divorce is considered to have violated the rules of religion, so she will be threatened to go to hell. Even, implicitly it is described that in whatever condition, a wife is not allowed to propose a divorce. This view either intentionally or unintentionally shows the unfairness of a judge to women victims and even tends to discredit and blame the women. The judge's view leads to the increasingly worse women's position and causes unequal gender relations because the judge does not use the gender perspective in understanding the issue of domestic violence experienced by women. This will certainly be an obstacle in providing services to women victims of domestic violence.

As expressed by an informant from the Religious Court (BB):

"Nowadays many wives dare to propose a divorce to husbands; they no longer fear of sins, perhaps it is because of the influence of gender view" (Interview on January 11, 2013).

The informant's expression above describes how policy makers are still mostly affected by patriarchal way of thinking and culture, considering the wife is not entitled to access to divorce or to control her rights of life. The patriarchal culture can also because of religious interpretations. The description from the two informants above shows how an understanding of religion is used as a justification for the interpretation of the patriarchal culture which is gender biased against women, whereas such patriarchal understanding of the two informants above will clearly violate the principles and religious values that emphasize on the principles of truth, justice, equal rights and principles (alhurriyyah) of liberation or independence. Patriarchy culture also 
leads to a mindset which assumes that men dominate and women are controlled, men as leaders while women are led, thus resulting in the attitude and behavior of the husband whose wishes are to be followed even when his wife has proposed a divorce.

Personality. Personally mindset and the way people think is still difficult to change, many women have assumption that if the existence of domestic violence case is caused by women's fault, sometimes even victims also feel that they deserve the treatment of the husband because the husband is the head of the family and is considered to have a full power. Safilios Rothschild (1970) says that the power structure of the family is on three components; authority (who is considered to have the legitimacy to decide, according to the culture and norms), decision maker (who most frequently makes decisions) and influence (who is influential). Sociologically and anthropologically, since men are considered the head of family and living provider, then women are regarded as subordinate to men, even Marxist feminism theory assumes that violence against women occurs through a product of political, social and economic structure that is closely related to capitalism. Prominent figure of Marxist feminism, Frederich Engel, a German philosopher, in his book The Origin of the Family, shows the big influence of material conditions on the family organization. He begins to illustrate that in this world women and men originally had no marriage bond. They were equally free to decide to whom they wanted to have sex or it can be said all married all, so that they could frequently change sexual partners until they came to the time when the natural selection products of women population were fewer than those of men because many men did not want to let their women go. Since then, there were regular partners. (Engels, 1972).

Engel said that the society at that time was a matrilineal society (maternal lineage) and also matriarchal society (women had economic and political power). Then, animal hunting dominated and became an important livelihood. The number of animals hunted was an important source for a power shift; the division of work began to form. Females began to be confined at home jobs, and their jobs were no longer considered important because men now had more value than women. Not only the hunting but also the hunting results, in addition to the use for meal, could be exchanged for other goods premises so that the yields increasingly valued men and women yields were more under-appreciated. Men became more central and often became the decision makers. Until finally men ended their matrilineal line and line and replaced it with patriarchal desire line to inherit their property. The rights of mother were terminated. Engel says that at that time "error of history of the world for the female sex" occurred (Engels, 1972).

The results showed that there were several victims who considered it reasonable to justify and think of the behavior of husband who committed violence to the wife as expressed by an informant:

"I sincerely accept such action by my husband because I feel that it is already my qodrat (nature) as a woman. I can only hope one day my husband realizes his mistakes, and he repents and changes" (Interview on 10 April 2013)

Even when asked for why not reported her husband's behavior to his employer in order to get sanctions or to the authorities in order to be punished according to his deeds, victims still felt sorry if the actor/husband got sanctions from his employer let alone sent to jail.

The woman felt that the treatment and acts of violence committed by her husband against her was considered the nature to be received sincerely by the wife. Personally, many women do not understand what is meant by nature. Theoretically, there is a difference between nature and gender. Motahhari, an Iranian philosopher quoted by Rahman (2000b) says that in Al-Qu'ran there is no trace that women were created from materials that were lower than men's or women's disparaging views regarding the nature and structure. According to Shihab in Umar (1999), in the view of Islam, God created all things by nature "Verily, We have created all things with Qadar" (Quran surah al Qomar/54:49). By the experts, qodrat here is defined as "the size, properties that God set for all things" and this is qodrat (nature). Thus, male or female, as an individual has each the qodrat. Jember community members including women often assume that what is experienced in their households has already been a qodrat. As a result, according to Umar, (1999:6), women (and men) are stuck on the limitations which are not really absolute provisions intended for them, and then the ability of individual woman is neglected. In social life, the understanding of nature has important implications, particularly on women who have more prohibitions and restrictions of their social-cuktural roles. For example, the assumption that women's nature is in the kitchen, well, bed, or domestic roles. The implication is that if the woman (wife) cannot (will not) perform the roles of the so-called qodrat, then husband thinks he has the right to educate in the way men (and some women) are considered true. It often happens that, by educational reason, a husband is hitting the wife. In fact, this interpretation may have been constructed from the beginning to legitimize patriarchal power within and outside the household. In cultural studies, what is called "nature" of women is the difference between men and women based on the features of each sex that is not exchangeable, for example woman's menstruation, pregnancy, childbirth, which are called the nature of women. Therefore, according to Faqihuddin (2013:7), gender analysis should be viewed in the form of equitable relations between women and men. Gender must be sterilized of insular elements on nature, the distinction between natures. What does not belong to the nature of the relationship between women and men is an important concept to parse the issue of 
violence against women. Violence is commonly referred to sexuality, and what is said as non-nature is often called gender.

If the woman (wife) always assumes that the violence experienced by women is women's nature, the efforts to achieve equitable relationships in the family will have constraints that are difficult to change. Therefore, it is necessary to undertake very strategic efforts to change the cultural system of paradigm shift in the perspective and to provide an understanding and awareness of the thinking patterns of women and men (society). If this is not done, it will be very difficult to achieve equitable gender relations, including in providing services to women victims of domestic violence from the perspective of gender equality.

Personally, many victims have lack of understanding of the women's rights. They still have a lot of understanding and belief that the husband is not wrong to commit such violence against her. Therefore, many women victims of domestic violence receive behavioral injustice done by husbands because they have accepted the values through cultural system or religious values they received. Even they often found violent behaviors done by their parents, so this eventually becomes a justification for acts of violence committed by a husband to the wife.

Thought pattern of society including women still assumes that the women's tasks are educating children at home and doing the domestic tasks which do not get similar appreciation as the men who work outside and can make money. This will have implications on unfair cultural treatment to women, including violence against women (wife) because the wife does not contribute to the economy. As stated by Margaret Beston (1969) that works at home do not get the same value as men in "community where money more significantly determines value. Women are considered the most major groups that are considered to have more works outside of economic aspect. He adds that women's work is not considered important because it does not have significant value. Thus, women who do the work without having this value are not considered to have the same value as her husband because it does not make money. Dair Gillespie (1971) emphasizes that power is associated with the involvement in the economic system. According to him, it is very clear that, to wife, for achieving power they must have financial resources. They must participate in economic aspect, and their educational level should be equivalent to or even higher than that of her husband.

The personality factor has also been a stand-alone determinant. Personality is related to a person's personal matters, for example, a woman feels her status is lower than that of her husband. Sociologically, it is known that women who have not changed their traditional consciousness will position themselves as the objects of their husband,. If this unequal feeling rapidly increases, a woman feels to be subordinate to her husband. The unequal gender relation is regarded as taqdir which must be accepted by women.

Analysis of liberal feminism. Alison Jaggar in her book Feminist, politics and Human nature suggests that in the liberal thought the unique nature of human is the rationality. To those with this type of thought, it is not a classic argument that mind distinguishes man from other creatures (Jagger, 1993:3). Theory of liberalism emphasizes that fair society allows the individual to practice its own autonomy, and to the liberals, filling the rights should be prioritized (Sandel ed; 1984:4). What is desired by liberal feminism is to liberate women and operational gender roles. In patriarchal society, the role of women is assumed to fit in a few areas, such as teacher, nurse, secretary, since the works are associated with the feminist nature.

Historical development of liberal feminist thought in 18th century. Wollstone Craft in his book: A Vindication of the rights of women describes that middle-class women have sacrificed the health of freedom and must feel proud of the progress that is not generated by the woman but by her husband. Wollstone Craft offers a way out; women should be given the freedom to obtain an education equal to men, so that women are able to safeguard themselves, not a part of men. Thus, women are not tools to achieve men's happiness.

Struat Mills and Harriet suggest that women be more daring to express their desires to achieve happiness. Betty Frieden, known as liberal feminism figure of the 20th century, in her book The Feminist Mystique, says that middle-class women who live in rural areas of city follow the wives' traditional role to be housewives that make them feel empty and not able to grow and can only clean the floor, keep children and cook. The way out offered by Frieden is supporting housewives to return to school and study for a higher education in order to gain self-identity, equality, political power, but it does not mean to stop loving husband and children (Frieden 1979: 380). The solution offered by Frieden is that women should cooperate with men to make changes in public values, leadership, institutional structure, and private field. In household, Frieden suggests that the husbands should change their habits to be more aware of family affairs and begin to carry the family burden of together ranging from economy, home and children.

Interpretation of Religious Doctrines. Interpretation of religious teachings which is not in accordance with the principles of religion is one of the barriers in providing services to women victims of domestic violence. Many people still have the notion that in religion the husband's position is higher as the leader than the wife. As the leader, the husband has the rights to do anything with the reasons that lead to goodness. Similarly, woman or wife as the one to be led must follow according to what is said by the leader. If what is desired by the leader is not met, it is very reasonable and right for the leader to hit the wife. Such belief departs from the way 
of understanding Quran surah 4 verse 34. In this verse, there is a word qowwamun which is translated as leader. This will imply that the husband should be able to be a leader for his wife, and a leader can do anything for the sake of goodness. In fact, there is a scholar who interprets the word qowwamun not in meaning of leader but as a sustainer, protector or helper. Subhan (2002.26) in Satar explains the word "Qowwamuna" in surah 4:34 has the meaning of "sustainer, protector, enforcer, man-in-charge and guarantor" when associated with the obligation of the husband to provide living. Meanwhile, the word "arrijal", according to Subhan, is not merely the plural form of "rajul" but can also come from the word "rijl" (leg) and "rojil" (people who strive, seek rizqi which is synonymous with public activities). Thus, according to Subhan, the word "Rijal" refers to any male or female who is more active and "annisa" for those who stay at home despite their biological status as male or female.

Likewise, the words "fadlribuhunna" are translated into "beat them". In fact, many scholars interpret "fadhribuhunna" not "beat them". If still interpreted as "beat them", it is not the beat that hurts but only uses Siwak or handkerchief. Interpretation of the above two sentences will have implications on the cultural system and social system of society, both men and women as once expressed by Mrs. Lilik, BPPKB chairman. Even the argument of the Quran which is interpreted with particular meaning acts causes the justification of beating wife, and this is followed by some public officials and most perpetrators of domestic violence to justify their actions. As expressed by ER when assisting victims, the judge even said "Why did your husband beat you? Did you not obey your husband? This notion is because of the assumption that husband is the leader who can do anything including beating his wife if she does not obey and follow the husband. This is prompted by the interpretation of religious doctrine that does not comply with the principles of religious teachings. An improper interpretation of religious teachings will have implications on unequal gender relations and leads to the emergence of the acts of injustice and domestic violence.

Barriers of Regulation System. The existence of a rule that domestic violence is a crime on complaint will also be an obstacle in providing services to women victims of domestic violence, such as psychological violence, economic neglect, and sexual violence. Because they are considered crimes on complaint, the companion or police cannot proceed and penalize the perpetrators of domestic violence if the victims did not file a lawsuit or complaint to the authorities. Although Griya Asih, Complaint Center, PPT District or Sub-District Police Stations are ready to serve for 24 hours, since domestic violence is a crime on complaint, the officers in the field cannot do much then if the victims did not file a complaint and lawsuit. The officers will suggest the victims have the courage to report their cases to the authorities or to Griya Asih or Complaint Center or to PPT. It is expected that there is a paradigm shift from community members who used to feel frightened by the husband's threat or feel shy to open disgrace of the family to have the courage to report the abuse, as explained in figure 5.10. It is explained that a victim reports a case of domestic violence in the household and reports to the Police of Jember. In order that victims do not feel fear when dealing with the police, then the police officers in charge, particular those in Unit of PPA Service Room Jember, are not wearing police uniforms and attributes. This is a trick of Jember Police to make women victims have the courage to report their cases.

Strategy and Implementation of Services to Women Victims of Domestic Violence Associated with Gender Fairness. Strategy and performance of local government in implementing the service policy to women victims of domestic violence is among others by using a cultural approach. Regency government attempts to understand local culture of community members of Jember especially those in rural areas. Therefore, the local government is trying to explore positive things that already exist in society, especially policies that can help implement services to women victims of domestic violence, ranging from UUPKDRT (Law on Domestic Violence Prevention), Local Regulations and Regenct's Regulations. This is not a top-down approach but bottom-up approach. Officials notice the culture that is commonly practiced in the society by accommodating the existing cultures on which the government policies are then adjusted. For example, because Jember people have already been familiar with religious gatherings such as Yasin Tahlil group, dhibaan group, or a collection of arts and others, then government programs simply adjust the ideas and creativity that already exist. Furthermore, in order that the available ideas in society are legal and protected by government, it is important for the government to strengthen those ideas by the establishment of Local Regulations or Regent's Regulations or Decrees. This is the history of the foundation of Griya Asih.

Based on observations and interviews in the field, there were several strategies pursued by governments in the prevention, management, and elimination of domestic violence in Jember Regency by cultural approach through PKK which has boards from neighborhood level called dasa wisma (in every 10 families there are caring administrators) to the central level. This approach was carried out through the stages of prevention, handling and recovery of victims. Coordinative prevention of domestic violence is a program of BPPKB, Police, Education Department and PKK Work Group 1, but in order to make the implementation more effective, the efforts are made by the Jember Regency Government with cross-sector private sectors, NGOs, religious-social organizations, PKK Jember with all the work fields/groups. 
The efforts to prevent domestic violence are also undertaken by cultural approach through religious gathering group including yasin tahlil groups. Yasin tahlil activities are usually done by members of NU organization, Muslimat and Fatayat (NU Women Organizations) by reading a few good sentences and Quranic verses. After the completion of tahlilan, the board of Griya Asih who is also a religious figure or organization companion or complaint center or PPT will provide socialization on the existing laws. Dhibaan group is reading sholawat for the Prophet with a variety of songs and the history of the history of struggle of Prophet Muhammad. After the event, it is then continued with the socialization on laws and Griya Asih and also various social, religious issues. Socialization is also undertaken through farmer groups during the discussion of agricultural issues among farmers. The companion and caretaker of Griya Asih always come to socialize various laws. Kadarkum (legally aware family) group; Socializations on various laws, Griya Asih and PPT are also done through Kadarkum groups. Kadarkum is legally aware family group consisting of approximately 25 people, men and women, from various elements in the society. This group always meets on a regular basis in accordance with the agreement of members and has the objective to empower the community through awareness of the existing laws.

Cultural approach is also carried out through a game of simulation group. It is also inserted with singing or reading sholawat while playing this simulation. Simulation game is one way to socialize various laws and religious values through a game. One group consists of 11 players and coupled with the audience without limitation in number.

The management and services to women victims of domestic violence also use cultural approach, by paying attention to local culture. The handling of the case is undertaken as well as possible starting from the smallest area, that is, dasa wisma (a group of 10 houses in a neighborhood). Based on the field observations and in-depth interviews, it can be described that handling by cultural approach was often performed by a companion from dasa wisma. In the case of women experiencing violence in the family, the companion is trying to listen to the victim(s) and then talks about the rights of the victim(s) and the punishment for the perpetrator(s). After that, he/she calls the offender and asks for the truth of the behavior towards his wife. He will declare that what the offender did violates the law and is in conflict with the religious values and principles. Furthermore, if the victim asks for his case to be brought to legal side, then the companion will accompany her to Griya Asih in the village. Subsequently, the case is transferred to PPT in Jember Regency.

Recovery effort is carried out by mentoring the victim to get medical care (outpatient or inpatient). The victim is also provided with training on independence and stimulus assistance to start a business. The recovery effort is based on the idea that the recovery of victims of domestic violence should be interpreted broadly, not only legal, medical and psycho-social interventions, but also the creation of situation where domestic violence victims can be re-empowered in whole, so they can take decisions in their life and re-run their roles. This action requires not only the seriousness of one or two institutions but also the support and involvement of various elements including society, family and business people. The implementation of recovery efforts is also in cooperation with the existing employers in the region where domestic violence victims are domiciled. If the victims live in an area with culturally specific works that can be reserved for developing the victims' potentials, then the victims will be given the opportunity to sharpen their potentials in hope that after the incidence the victims will be more economically independent and more confident because they have the work that could have the raise their self-esteem as human beings.

In the prevention, treatment, services and recovery of victims of violence on women, in particular domestic violence, the main tasks are on coordination of BPPKB, Police, PKK Jember regency and related Cross-Sector Agencies. Other institutions/organizations have formed units of service by cultural approach which easily accessible, familiar and close to the victim's environment. Griya Asih is a place to conduct a variety of empowerment activities, particularly in the field of legal empowerment. This can be a place for socializing various laws and could be used as a place for community expressions in many cases, especially the main cases of domestic violence. The place is also to provide assistance to the victims if they want the case to be prosecuted until the case obtains a decision from the Religious Court or District Court or to transfer the case to PPT.

Complaint center is a place for delivery of service, settlement and prevention of domestic violence in Jember in total of 31 (thirty one) units located in each district. Based on observations in the field and interviews, it can be described that the more complete unit services for victims of violence on women and children are organized by Integrated Service Center for Crimes of Trafficking, Violence on Women and Children Jember Regency (PPT Jember). The services provided by PPT Jember are not only from Complaint Center for Victims of Trafficking, Domestic Violence and Child Protection of Districts but also referral from Griya Asih.

Prevention, treatment and services with highly effective and efficient approach to cultural arts by bottom up model are carried out through hadrah, samroh, Mocopat, Street Music and PIK.R and Karang Taruna (Youth Organization at village level). Hadrah consists of group of teenagers, men or women who siing Sholawat or religious songs accompanied by traditional music instrument that is specifically made to accompany the performing art. Samroh is almost similar with hadrah, but Samroh has more players or teenagers, women, and 
the instruments used are almost the same as hadrah. Samrah becomes the characteristic of certain pesantren (Islamic boarding school) or certain Islamic colleges. In the prevention and services of domestic violence cases, through samroh, Sholawat is sung followed by poems which have messages not to do domestic violence or to treat wife, husband or children with compassionately and wisely. Mocopat is a traditional art which is usually done by men by using traditional instruments. It usually uses local language rhymes with rhyme beautifully conveyed in the message in mocopat. Mocopat also composes the message of prevention and prohibition of committing domestic violence. Street children music in Jember Regency gets special attention from the local government to be empowered in order to optimize street children art and music professionally. Street children music also conveys message of prohibition of committing domestic violence. Music group PIK.R., Karang Taruna, and Center for Youth information and Counseling also have music groups that deliver messages singing songs.

The strategy of regency government in the prevention, treatment and services to women victims of domestic violence can also be performed by structural approach to revitalizing the organization. According to Sinambela (2008), the revitalization is prompted by the problem of poor organization and lack of capability and effectiveness of the organization, so it is necessary to improve the organization, work procedures and governance services to public. In addition, it is required to hold an organizational restructuring in order to deal with changes. Based on the observations and in-depth interviews and efforts of prevention, treatment and services to women victims of domestic violence, Jember regency takes structural approach by the establishment of regulations concerning the protection of women and children. Then, Regent's regulation on the establishment of PPT followed by Regent's Decree of Complaint Center formation and Griya Asih, which are organizationally under guidance of TP. PKK. These are all done in order to provide services to public in cases of domestic violence and to make it closer to society making it easily affordable and more easily accessible to public. The commitment built by Jember government, especially BPPKB which that structurally has been under supervision of PPT (integrated service center). The involvement of the other Social Services is really essential such as Department of Education, Legal Section, Public Relations, Welfare Section, Police of Jember District, etc.

The results showed that the implementation of the policy on services for women victims of domestic violence was carried out by involving cross-sector strategies by synergizing Work Programs, especially services of prevention and handling of domestic violence cases in Jember Regency conducted in cooperation with institutions/agencies in accordance with each institution, but their participations were in line with the budget plan allocated for the efforts of prevention, services and handling of domestic violence cases. Cooperation had been undertaken by making MOUs with various cross-sector institutions.

Public participation is one of the strategies of regency government in order to provide good and correct services by the maximum involvement of public in the prevention, treatment and services to women victims of domestic violence. The public participation is the synergy between NGOs, business people, PKK and religious organizations. Public participation is undertaken in the hope of lowering even removing the number of domestic violence. The public participation can ultimately determine service priority. Many benefits can be taken when the government involves the society. In determining policy direction and implementation of policies in the form of services to women victims of domestic violence, public participation will automatically affect the empowerment of society, especially the lower class, so that people will understand the various laws and policies that prioritize victims and gender fairness. The results showed that the public involvement in the prevention, treatment and services to women victims of domestic violence is clear, for example, in every dasa wisma there are personnel who are always ready to participate.

In terms of the importance of community participation, Tjiptono (1997) explains that the community involvement in public services will be able to determine the realization of better quality of service. The public involvement in providing assessment of the service provided by the government either personally or through organization will be able to affect the operation of the public services. The observations and interviews showed that the building up work partners by public participation with NGOs, business people, PKK, community leaders and various elements that exist in the community had been running well, but the involvement of the community for the areas dominated by Madurese ethnic such as Kamal village and Suco Pangepok village was not optimal because Dasa Wisma and Griya Asih did not participate fully.

The utilization of information technology is one of the strategies of regency government in providing the best services to the community. Opportunities to provide access to information to the public through information technology is a strategic opportunity that can be used well since the messages can be conveyed efficiently and effectively. Based on observations and interviews, there are several strategies in using technology to socialize various existing laws, especially the Law on Elimination of Domestic Violence using $\mathrm{TV}$, radio and books. 


\section{Conclusion}

Women victims of domestic violence expect all parties to respect their decision to divorce with their husbands who has committed violence. The form of respect is by facilitation and acceleration of the process either in scope of institutions where the husbands/women work, the prosecutor and the court. Meanwhile, Jember Regency government provides support through 12 organizations/government agencies as well as three non-governmental organizations for women empowerment, including the protection of women and children. However, these activities are still experiencing some constraints of structural aspect, patriarchal culture, personality, interpretation of religious teachings and regulation system. Meanwhile, the strategy used in the implementation of services to women victims of domestic violence associated with gender equity is by top down and bottom up approach.

\section{References}

[1]. Abdul Qodir, Faqihuddin, 2013.Refrensi bagi Hakim Peradilan Agama, Komnas Perempuan .Jakarta.

[2]. Betty Frieden 1963 Feminine mystique, the scond stage. 1981

[3]. Engels, Frederich. 1972(1884).The Origin of the FamilyPrivate, Property and thetates. New York: Partfinder Press.

[4]. Gillespie.Dair. 1971 " Who has the Power ? The Marital Struggle. Journal of Morriage and the Famimily ; 33

[5]. Jannah, Fathul,et al. 2003.Kekerasan Terhadap Istri. Yogyakarta: LKis Yogyakarta.

[6]. Keban, Yaremias. 2008.Enam Diemensi Strategis Administrasi Publik, Konsep Teori dan Isu.Gavamedia.

[7]. Kleden, Paulus Budi, et al. 2009. Memecah Kebisuan, Agama Mendengar Suara Perempuan Korban Kekerasan dalam Rumah Demi Keadilan, Respon Katolik. Komnas Perempuan. Open Society Institute.

[8]. Noerjannah, Djohantini, et al. 2009.Memecah Kebisuan, Agama Mendengar Suara Perempuan Korban Kekerasan Demi keadilan, Respon Muhammadiyah, Komnas Perempuan. Open Society Institute

[9]. Subhan, Zaitunah.1999.Tafsir Kebencian. Yogyakarta: Lkis

[10]. Thoha, Miftah. 2011.Ilmu Administrasi Publik Kontemporer. Yogyakarta: Kencana Prenada Media Group

[11]. Widodo, Joko, 2006, Pembangunan Birokrasi Berbasis Kinerja, Malang :Bangus Media Publishing Malang.

[12]. Widodo, Joko. 2011.Good Governance Telaah dari Dimensi Akuntabilitas dan Control Birokrasi pada Era Desentralisasi dan Otonomi Daerah.Surabaya.

[13]. Yuswadi. 2005.Methode Penelitian Sosial dan Humaniora Suatu Kompensasi Pendekatan Kuantitatif dan Kwalitatif.(Buku Materi Kuliah, Fakultas Ilmu Sosial dan Ilmu Politik Universitas Jember).

[14]. Yuswadi. 2008. Kebijakan Publik : Teori dan Proses. Yogyakarta : Media Presindo. 